\title{
Thema: Toezicht op het accountantsberoep
}

\section{Ruud Vergoossen en Philip Wallage}

Het toezicht op het accountantsberoep wordt momenteel wereldwijd aangescherpt. Dit is met name een gevolg van de financiële debacles in de afgelopen jaren, zoals die bij Enron, Worldcom, Parmalat en Ahold. Het vertrouwen van het beleggende publiek in de integere en transparante werking van de kapitaalmarkten is danig geschonden. De accountant belast met de controle van de financiële verslaggeving speelt een belangrijke rol bij de goede werking van de kapitaalmarkten. Het publiek en de politiek zijn gaan aandringen op onafhankelijk toezicht op het accountantsberoep. In de Verenigde Staten werd deze roep in 2002 beantwoord door het uitvaardigen van de Sarbanes-Oxley Act. Op grond van deze wet is een nieuwe toezichthouder op het accountantsberoep, de Public Company Accounting Oversight Board, opgericht. Daarmee is in de Verenigde Staten een einde gekomen aan (elke vorm van) zelfregulering door het accountantsberoep. In de Europese Unie is de behoefte aan toezicht op het accountantsberoep niet alleen aangewakkerd door de nieuwe Amerikaanse wetgeving, maar ook door de 'Europese' bedrijfsschandalen. Het concept van de herziene Achtste Richtlijn Vennootschapsrecht inzake de accountantscontrole vereist dan ook dat in de landen van de Europese Unie onafhankelijk toezicht op het accountantsberoep wordt ingevoerd. In Nederland wordt hieraan door middel van de Wet toezicht accountantsorganisaties (Wta) invulling gegeven. Volgens het ontwerp van deze wet zal de Autoriteit Financiële Markten (AFM) dit toezicht gaan uitvoeren. Alle reden dus om door middel van een themanummer aandacht te besteden aan enkele in het oog springende ontwikkelingen met betrekking tot het toezicht op het accountantsberoep.

In de eerste bijdrage geven wij een overzicht van een aantal belangrijke elementen van het toezicht zoals dat is vormgegeven in de Verenigde Staten en wordt ontwikkeld in het Verenigd Koninkrijk, Nederland en Duitsland. Aan de orde komen zaken als de registratie van accountantsorganisaties, de vormgeving van de kwaliteitstoetsing door middel van inspecties, de bevoegdheid tot het uitvaardigen van standaarden op het gebied van de accountantscontrole en de beroepsreglementering en de bestraffing van accountant(kantoren) bij overtreding van wet- en regelgeving. In het tweede artikel gaan Pouw, Sebrechts en Sturmans in op de Wta. Zoals gezegd, gaat de AFM de eindverantwoordelijkheid dragen voor het aanstaande toezicht op het accountantsberoep in Nederland. Efficiënt en effectief toezicht vereisen echter ook de inbreng van de bestaande beroepsorganisaties. Maar de auteurs merken op dat een ongewenste vermenging van taken niet bijdraagt aan het herwinnen van het vertrouwen in het accountantsberoep. Het opstellen van regels, het toezien op de naleving van deze regels en de uiteindelijke bestraffing moeten dan ook strikt van elkaar gescheiden blijven. Het sluitstuk van effectief toezicht wordt gevormd door een onafhankelijke rechtspraak. Daar waar mogelijk zal het oordeel van de bestuursrechter worden gevraagd. In die gevallen dat het meer om de techniek van een accountantscontrole gaat, zal de nog in het leven te roepen Accountantskamer haar oordeel uitspreken.

Een kritische bespreking van de (toekomstige) taken van de AFM en het toezicht op de AFM wordt in de derde bijdrage geleverd door Beckman en De Jong. $\mathrm{Zij}$ plaatsen enkele vraagtekens bij de huidige en toekomstige taken van de AFM en gaan in op de relatie tussen de minister en de AFM in het kader van de diverse toezichtwetten en de lacunes die die relatie lijkt te vertonen. Voorts staan zij stil bij de beoogde bundeling van het toezicht op het accountantsberoep en het toezicht op de financiële verslaggeving bij de AFM. De auteurs vinden die bundeling niet gewenst aangezien de AFM op die manier informatie die zij op basis van haar ene toezichthoudende taak ter kennis krijgt, kan gebruiken in het kader van haar andere toezichthoudende taak. 